\title{
Lead poisoning due to geophagia: The consumption of miniature pottery
}

\author{
Ashley Phipps, Heather Fels, Mackenzie S. Burns, Shawn L. Gerstenberger* \\ Department of Environmental and Occupational Health, University of Nevada-Las Vegas, Las Vegas, USA \\ Email: * shawn.gerstenberger@unlv.edu
}

Received 15 August 2011; revised 5 December 2011; accepted 6 January 2012

\begin{abstract}
Geophagia (the pica of pottery, clay, earth, or dirt) is practiced before and during pregnancy in several countries, including Mexico, Turkey, Australia, and some African countries, and has been linked with cultural fertility beliefs and the satisfaction of cravings. Unfortunately, consumption of contaminated pottery can represent a source of lead exposure. Concerns regarding ingested pottery are two-fold; first, that people consuming these pots might be exposed to high concentrations of lead, and, second, that ingestion of these pots by pregnant women could result in elevated in utero lead exposure for the fetus. Very few published articles exist on this topic. In an effort to investigate "pot eating", this study aims to summarize published case studies on lead poisonings resulting from consumption of contaminated pottery. Additionally, several pottery items that are sold for the purpose of consumption were located and analyzed. This paper investigates the risk that "pot eating” poses by reviewing the literature, examining case studies, and analyzing the availability and lead concentration of edible pottery. Preliminary research indicates that although it is not common, "pot eating" can represent a high-risk lead exposure for pregnant women and their fetuses.
\end{abstract}

Keywords: Pica; Geophagia; Pottery; Lead; In Utero Blood Lead Levels; Metals; Systematic Review

\section{INTRODUCTION}

Geophagia, the pica of pottery, clay, earth, or dirt, is a significant source of lead that has been reported throughout history by many authors ranging from Roman physicians to 18th century explorers [1]. It has been strongly linked with both the satisfaction of cravings during pregnancy and cultural beliefs that the consuming clay increases fertility. Clay has been eaten as a fertility food

*Corresponding author. in Turkey, Mexico, Africa, and in aboriginal populations in Australia [2-6]. Additionally, pica has been associated with diets that are low in iron, zinc, and calcium [7]. During pregnancy, women in many communities not only recognize this "pot eating” behavior as a satisfaction of cravings, but also as a provision of necessary vitamins and minerals needed during pregnancy. The practices of culturally-linked geophagia have also immigrated, and geophagia has been observed repeatedly among Mexican immigrants to the United States [3,8].

Unfortunately, the ingestion of pottery that is contaminated with lead, typically due to lead-based paints or glazes, may represent an important and dangerous source of lead exposure for both the mother and the fetus [1]. Lead-poisoning caused by the ingestion of foods or liquids prepared in lead-contaminated pottery is well documented throughout the world [9]. Although the risks of exposure to foods cooked or stored in lead-contaminated pottery have been well researched, the direct ingestion of pottery, especially by pregnant women, has rarely been investigated.

Concerns regarding the culturally-linked ingestion of pottery are two-fold: first, that women consuming these pots might be exposed to high concentrations of lead, and, second, that ingestion of these pots by pregnant women could result in elevated in utero lead exposure to the fetus. Very few published articles exist on edible pottery, the extent of "pot eating" behavior, or acute and chronic health impacts on the mother and fetus. In an effort to investigate the culturally-linked behavior of "pot eating" and the availability and contamination of edible pottery items, this study aims to summarize existing published case studies on lead poisonings and elevated BLLs resulting from "pot eating" behavior. Additionally, the research team at the University of Nevada, Las Vegas (UNLV) located and purchased miniature edible pots from a swap meet in Chicago, Illinois. The pots were brought back to Las Vegas for confirmatory analysis. The objective of this paper is to investigate the risk that "pot eating" behavior poses by reviewing the literature, examining published case studies, and analyzing lead con- 
centration of currently available pottery.

\section{LEAD IN POTTERY AND POTTERY GLAZES}

In 1970, lead in gasoline, which had long been used as an anti-knocking agent, was banned by the US Legislature. Seven years later, the maximum concentrations of lead in paints were set at $0.06 \%$ [10]. The removal of lead from gasoline and paints led to considerable decreases in environmental lead exposure, but chronic exposures to lower concentrations of environmental lead still exist today in the United States and throughout the world. Although many common uses of lead are gradually being phased out, lead is currently used in commercial products, including glazes and paints used to decorate pottery, ceramics, and earthenware [11]. When contaminated dishes are used to cook acidic foods, such as tomatoes and chili, lead from the pottery is more likely to leach into the foods. This phenomenon is especially true when foods are cooked in contaminated dishes for several hours, which explains the strong associations observed between pottery use and elevated blood lead levels [9].

Several studies have associated use of lead-contaminated pottery with elevated blood lead levels (BLLs) in women and children. Research in a rural community in Mexico found a significant association between lead in blood and food storage in lead-glazed ceramics and cooking in lead-glazed ceramics [12]. Avila et al. [9], found that use of lead glazed ceramics to prepare food was a significant ( $t$-test, $\mathrm{p}<0.005$ ) determinant of elevated BLLs in women. Family use of lead-glazed pottery significantly ( $p=0.006$ ) elevated blood lead levels in children in another study, and the effect magnified as age increased (Age $\times$ Pottery Interaction, $p=0.014$ ) [13] Based on this and other research, it is believed that leadglazed ceramics represent a serious concern for chronic lead exposure, especially in young children and pregnant women.

\section{TOXICITY OF LEAD IN HUMANS}

The principle toxic effects of lead occur in the liver, kidney, and central nervous system. Lead mimics calcium and, thereby, alters the normal functioning of these biologic systems [14]. In the liver, lead interferes with heme synthesis, leading to anemia and the inhibition of erythrocyte pyrimindine-5-nucleotidase, which normally breaks down pyrimidine nucleotides. In the kidneys, lead primarily targets the proximal tubule of the nephrons, where it causes suppressed resorption of glucose, phosphate, and amino acids. This suppression can lead to glycosuria, aminoaciduria, and a hyperphospaturia with hypophospatemia [15].

The most serious and irreversible effects of lead expo- sure occur in the central nervous system, where lead can distort enzymes and structural proteins [16]. Additionally, many of lead's damaging effects can be attributed to its ability to compete with or mimic calcium. Even at very low concentrations, lead can compete with calcium for binding sites throughout the body. In the central nervous system, lead can affect neuronal signaling by competing with cerebellar phosphokinase C [17]. Lead can also inhibit calcium's passage through the cell membrane. When lead is absorbed by the mitochondria, where it distorts the cristae, cellular respiration is inhibited and other calcium reactions, including energy coupling, are also affected [18].

Research continues to indicate that there is no safe threshold BLL for lead in infants and young children. Although the results of acute lead exposure may be reversible with chelating treatment, chronic lead exposure may cause irreversible dysfunction and morphologic changes, resulting in eventual renal failure and death [15]. Permanent deleterious effects of chronic lead exposure have been observed in children with BLLs, well below $10 \mu \mathrm{g} / \mathrm{dL}$, the current "level of concern" [11,19]. Often, the first visible symptoms of lead toxicity are exhibited as mild behavioral alterations or flu-like symptoms, which can easily go undiagnosed. At increasing doses, clinical symptoms become more obvious, with abdominal pain, arthralgia, clumsiness and headache presenting as the most common early signs of encephalopathy. Untreated, the condition may progress to include loss of consciousness, stupor, and convulsions. Many children who recover from clinical encephalopathy retain serious, life-long cognitive, attention, and behavioral impairments [20]. Lead can also cause other serious long-term effects, ranging from hypertension and renal failure to adverse effects on reproduction [21].

\section{LEAD TOXICOLOGY DURING PREGNANCY}

There is indirect evidence that bone lead stores reenter circulation and raise circulating maternal blood lead levels during pregnancy, raise blood lead levels of the umbilical cord at term, and raise postpartum blood lead of the mother $[13,22,23]$. Investigations have shown that heavy metals, including lead, cross the barrier of the placenta and are transported to the fetus [24]. Research suggests that it is reasonable to conclude that bone lead, which follows the same kinetic pathway as calcium, is a potential source of lead for the fetus [25]. Kinetic studies during pregnancy must take into account the complex relationship between mother, fetus, and placenta [26]. Additionally, the kinetics of three compartments-blood, soft tissue, and bone-is of great importance in lead toxicology research. 
An increase in blood volume and the growth requirements of the fetus place a significant calcium demand on the body of a pregnant woman [27]. The increased demand for calcium requires either an increased dietary uptake of calcium or an increased resorption of calcium from bone turnover. The cycle is complex and fluctuates with each trimester, as demonstrated by Purdie et al. [28], who found increased rates of calcium resorption from bones in early pregnancy, followed by increased rates of bone formation during later weeks. During the third trimester, a growing fetus retains approximately $250 \mathrm{mg}$ of calcium per day, representing an $1100 \mathrm{mg} /$ day requirement for the mother [25].

Several physiological factors modulate the movement of lead from maternal bone to the growing fetus. Both the total lead exposure and the rate of lead exposure influence the concentration and location of the maternal compartment, which in turn affects the bioavailability and mobilization of lead into the placenta and fetus [29]. The maternal body lead burden and available concentration is influenced by maternal age, as mineral metabolism is a key factor. Additionally, gestational age plays a role in mineral metabolism for both the mother and the infant. A growing fetus produces 1,25-dihdroxyvitamin $\mathrm{D}$, which regulates active calcium transport across the placenta. The most active transport of calcium occurs later in pregnancy, when synapses develop and arborization of the cerebellum and cortex occur. Unfortunately, this critical stage is susceptible to lead's ability to inhibit synapse formation, thus affecting neurodevelopment in the fetus [30].

Two types of studies have examined the relationship between maternal and fetal blood lead levels. A cross sectional study looking at women in differential stages of pregnancy found a decreasing relationship between trimester and blood lead, with little change after the second trimester [31]. Conversely, two longitudinal studies, which followed cohorts of women throughout their pregnancy, could not establish any clear trends in BLL across trimesters [32,33]. Although the longitudinal studies did find significant increases in lead concentration in fetal bones and organs throughout the course of gestation, the majority of research indicates that lead does not bioaccumulate in the fetus [34]. Additional studies that have compared maternal BLL to cord blood lead concentration found correlations of almost 1.0 [35].

\section{CHRONIC EFFECTS OF NEONATAL LEAD POISONING}

A study by Robinson, et al. [36], which analyzed the blood lead levels in cord blood, whole blood, and erythrocytes of 103 infants without a history of pica behavior or lead poisoning, found that infants between the ages of five hours and six months had a median blood lead concentration of $0.015 \mathrm{mg} / 100 \mathrm{ml}$ in whole blood and 0.034 $\mathrm{mg} / 100 \mathrm{ml}$ in erythrocytes [36]. As concentrations of lead in the blood of infants increases, chronic effects are observed. Research has shown that postnatal exposure to lead can result in mental retardation, learning deficits, or other neurological and behavioral problems later in life. More recent research has also found that a lasting learning impairment can be caused by gestational exposure to lead [37]. Results from this study indicate that up to two years of age, children with umbilical cord blood lead levels of 10 to $25 \mu \mathrm{g} / \mathrm{dL}$ achieve significantly lower scores on tests of cognitive development than do children with lower prenatal exposures [38]. The same research correlated higher prenatal lead exposure $(>10 \mu \mathrm{g} / \mathrm{dL}$ in cord blood) with less early cognitive development, at least through 24 months of age.

Fortunately, research has also found that by age five, the majority of children appear to have recovered from this early insult. By 57 months of age, children with a prenatal exposure to lead have statistically equivalent test scores when compared to children who were not exposed to lead prenatally [39]. The risk that a deficit will persist through the preschool years is shown to increase among children with a higher prenatal exposure and either higher postnatal exposure or less optimal sociodemographic characteristics [38]. Unfortunately, if chronic lead exposures do persist throughout the postnatal lifetime, the impairment is significant and irreversible, with an inverse relationship between body burden of lead and neuropsychological or cognitive performance [40].

\section{PUBLISHED CASE REPORTS}

In order to examine the clinical effects of neonatal lead poisoning, an extensive and complete review of the literature for cases was conducted. Clinical case reports that outlined the original data of cases in the United States of acute lead poisoning and elevated Blood Lead Level (BLL) (>10 $\mu \mathrm{g} / \mathrm{dL})$ were included in this review. Several scientific search engines were utilized, including: Medline, Academic Search Premier, PubMed, and Google Scholar. Articles were retrieved according to strategies outlined by the Cochrane Collaboration recommended search strategy, using the following search criteria: "pot eating”, pica behavior, lead, heavy metal, blood lead level, lead poisoning, etc. Ingestion of lead-contaminated pottery must have been cited as a contributing source of lead-poisoning and the BLL must have been measured by standard graphite furnace atomic absorption spectrophotometry or another acceptable methodology.

Only four cases of neonate and infant lead-poisoning have been published that identify lead-contaminated pottery as a major contributing risk factor [3,41-43]. The 
cases were from Texas, Illinois, California, and Hawaii, and the mothers were all identified as Hispanic, Latino, or Mexican-American. The infants' cord and blood lead levels (BLLs) ranged from 29.0 to $113.6 \mu \mathrm{g} / \mathrm{dL}$, while their mothers' BLLs ranged from 14.0 to $119.4 \mu \mathrm{g} / \mathrm{dL}$. Those infants whose cord blood was tested immediately after birth had much higher BLLs than the infants who were tested later in infancy. Only one of the suspected pottery items was available for analysis. It was analyzed with a portable X-Ray Fluorescence Spectrometer (XRF) and found to contain lead at a concentration of 25 $\mathrm{mg} / \mathrm{cm}^{2}$. One of the case reports noted that the lead exposure risk questionnaire did not address the issue of ingested lead-contaminated pottery as a direct source of exposure [43]. The cases are outlined in Table 1.

\section{LEAD-GLAZED POTTERY ANALYSIS}

Five small pots were collected at a flea market in Chicago, Illinois and can be seen in Figure 1. The collection of pottery was completed through an opportunistic sample, a randomized approach was not used. During conversations with the vendor, it was revealed that he has "regular" customers that purchase these pots in order to grind them into powder and ingest them as a home remedy. The pots ranged in size from approximately 1.0 to $15.0 \mathrm{~cm}$ and were glazed with an orange, red, or blue paints and glazes (Figure 1). The pots were analyzed by an independent laboratory (Forensic Analytical, Las Vegas, NV) using the Food and Drug Administration (FDA) Elemental Analysis Method EAM 4.1 [44], entitled Flame Atomic Absorption Spectrometric Determination of Lead and Cadmium Extracted from Ceramic Foodware, was utilized. In this procedure, lead is extracted from the ceramicware by filling it with $4 \%$ acetic acid to within $6.7 \mathrm{~mm}$ of overflowing. The acid leaches the lead from the vessel for 24 hours and $20^{\circ} \mathrm{C}-24^{\circ} \mathrm{C}(68$ $75^{\circ} \mathrm{F}$ ). A graphite furnace atomic absorption spectrometer (GFAAS), with background correction and a calibration curve with linear least squares regression, is used to determine lead concentration. This method is applicable to food-contact surfaces of silicate-based materials (earthenware, glazed ceramicware, decorated ceramicware, decorated glass, and lead crystal glass) and is capable of determining lead concentrations greater than approximately $1.0 \mu \mathrm{g} / \mathrm{mL}$ or parts per million (ppm) [44]. In addition to the leach testing, one of the samples was ground up and analyzed as a soil sample via GFAAS.

The results of the GFAAS analysis of lead concentration in the five edible pots are seen in Table 2 . The sample pots ranged in size and color; the glazes were brittle and were loose enough to chip or flake when handled. The range of concentrations of lead in the five pots was between 38,000 parts per million and 100,000 parts per million (or 1 percent) lead. The FDA guideline for small

Table 1. Cases of lead poisoning due to "pot eating” pica behavior.

\begin{tabular}{|c|c|c|c|c|c|c|c|}
\hline Reference & Location & Age/Sex & $\begin{array}{c}\text { Initial BLL } \\
(\mu \mathrm{g} / \mathrm{dL})\end{array}$ & Diagnosis & Outcome & Suspected Cause & $\begin{array}{l}\text { Lead Content } \\
\text { of Pottery }\end{array}$ \\
\hline \multirow{2}{*}{$\begin{array}{c}\text { Lowry } \\
\text { et al., } 2004\end{array}$} & \multirow[t]{2}{*}{ Jacksonville, Texas } & $11 \mathrm{mo} / \mathrm{F}^{\mathrm{a}}$ & 41 & $\begin{array}{l}\text { Diagnosed } \\
\text { on routine } \\
\text { screening }\end{array}$ & $\begin{array}{l}\text { Persistently } \\
\text { elevated BLL }\end{array}$ & \multirow{2}{*}{$\begin{array}{l}\text { Chewing lead-glazed } \\
\text { pottery during pregnancy. } \\
\text { Pica behavior in mother, } \\
\text { leading to an elevated } \\
\text { in utero BLL in child }\end{array}$} & \multirow[t]{2}{*}{$25 \mathrm{mg} / \mathrm{cm}^{2}$} \\
\hline & & Adult $/ \mathrm{F}^{\mathrm{a}}$ & 14 & $\begin{array}{l}\text { Child with } \\
\text { elevated BLL }\end{array}$ & $\mathrm{N} / \mathrm{A}$ & & \\
\hline \multirow{3}{*}{$\begin{array}{l}\text { Hamilton } \\
\text { et al., } 2001\end{array}$} & \multirow{3}{*}{$\begin{array}{l}\text { Los Angeles, } \\
\text { CA }\end{array}$} & & & \multirow{3}{*}{$\begin{array}{l}\text { Elevated BLL } \\
\text { diagnosed at } \\
\text { delivery }\end{array}$} & BLL dropped to & & \multirow{3}{*}{$\mathrm{N} / \mathrm{A}$} \\
\hline & & Newborn $^{\mathrm{b}}$ & $\begin{array}{l}113.6 \text { (umbilical } \\
\text { cord BLL) }\end{array}$ & & $\begin{array}{l}13 \mu \mathrm{g} / \mathrm{dL} \text {, child } \\
\text { reported to be } \\
\text { doing well }\end{array}$ & $\begin{array}{l}\text { Ingestion of lead-glazed } \\
\text { pottery during pregnancy. } \\
\text { Pica behavior in mother, }\end{array}$ & \\
\hline & & Adult/F $F^{b}$ & 119 & & $\begin{array}{l}\text { Dramatic } \\
\text { biochemical } \\
\text { improvement }\end{array}$ & $\begin{array}{l}\text { leading to an elevated } \\
\text { in utero BLL in child }\end{array}$ & \\
\hline \multirow{2}{*}{$\begin{array}{l}\text { Mycyk and } \\
\text { Leikin, } 2004\end{array}$} & \multirow{2}{*}{ Chicago, IL } & Newborn $^{c}$ & $\begin{array}{l}100 \text { (umbilical } \\
\text { cord BLL) }\end{array}$ & \multirow{2}{*}{$\begin{array}{l}\text { Elevated BLL } \\
\text { diagnosed at } \\
\text { delivery }\end{array}$} & Decreased BLL & & \multirow[t]{2}{*}{$\mathrm{N} / \mathrm{A}$} \\
\hline & & $34 \mathrm{yr} / \mathrm{F}^{\mathrm{c}}$ & $87-117$ & & N/A & & \\
\hline \multirow{3}{*}{$\begin{array}{c}\text { Erdem } \\
\text { et al., } 2004\end{array}$} & \multirow{3}{*}{ Honolulu, HI } & $1 \mathrm{mo} / \mathrm{M}^{\mathrm{d}}$ & 29 & $\begin{array}{l}\text { Sibling with } \\
\text { elevated BLL }\end{array}$ & $N / A$ & & \multirow{3}{*}{$\mathrm{N} / \mathrm{A}$} \\
\hline & & $22 \mathrm{yr} / \mathrm{F}^{\mathrm{d}}$ & 36 & $\begin{array}{l}\text { Child with } \\
\text { elevated BLL }\end{array}$ & N/A & & \\
\hline & & $3 \mathrm{yr} / \mathrm{F}^{\mathrm{d}}$ & 41 & $\begin{array}{l}\text { Diagnosed on } \\
\text { routine screening }\end{array}$ & Decreased BLL & $\begin{array}{l}\text { Child ingested } \\
\text { ground up pottery }\end{array}$ & \\
\hline
\end{tabular}

a, b, c, d Offspring (Same letter denotes a parent-child relationship). 


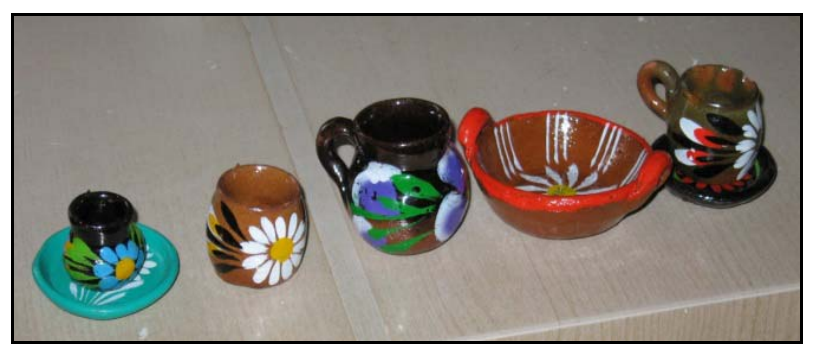

Figure 1. Photo of edible pottery used for "pot eating”.

Table 2. Graphite furnace atomic absorption spectrometer analysis of five edible lead-glazed pots ${ }^{\mathrm{a}}$.

\begin{tabular}{cccc}
\hline $\begin{array}{c}\text { Sample } \\
\text { Number }\end{array}$ & Analytical Method & Analyte & $\begin{array}{c}\text { Result } \\
(\mathrm{ppm})\end{array}$ \\
\hline 1 & & & 48,000 \\
2 & $\begin{array}{c}\text { Leach Testing, } \\
\text { EAM 4.1, }\end{array}$ & 10,000 \\
3 & IGFAAS Analysis & $\begin{array}{c}\text { Lead } \\
(\mathrm{Pb})\end{array}$ & 38,000 \\
4 & & & 10,000 \\
5 & $\begin{array}{c}\text { Soil Sample Method, } \\
\text { GFAAS Analysis }\end{array}$ & & 70,000 \\
\hline
\end{tabular}

${ }^{a}$ Pots were located in July 2006 and were analyzed by an independent laboratory in March 2007. ${ }^{\text {b }}$ This pot was ground into a powder using a mortar and pestle and was then analyzed as a soil sample.

ceramic hollowware is $2.0 \mathrm{ppm}$ [45]. However, these pottery items, which are intended for consumption, would be regulated by the FDA action limit of $0.5 \mathrm{ppm}$ which is applied to foods ingested by infants and pregnant women [46]. These pottery items contain, therefore, up to ten million times more lead contamination than is allowable by the FDA.

\section{DISCUSSION}

In order to reach the U.S. Department of Health and Human Services (HHS) goal of eliminating elevated BLLs in children by the year 2020, evidence supports the importance of a shift towards primary prevention of lead exposure. The practice of "pot eating", or pregnancyrelated, culturally-linked geophagic pica behavior, is an important issue to address when attempting to prevent exposure. However, it must be addressed with cultural sensitivity. This review is the first known attempt to compile and evaluate research on the potential risk of lead exposure associated with "pot eating". A lack of information has historically veiled a thorough understanding of the prevalence of "pot eating" and the potential impact of ingesting lead-contaminated pottery. Therefore, the most important prevention methods will be to increase awareness and to identify and remove contaminated pottery from the marketplace.

Data collected from both the literature and field indicate that the "pot eating" behavior does exist in com- munities in the United States and that pottery intended for ingestion during pregnancy is available. However, the rates of this practice are not known and should be determined. Additionally, the review of published case studies in the United States illustrates that there have been several documented instances where ingestion of lead-contaminated pottery during pregnancy has led to poisoning in both the mother and the developing fetus. Collection of five easily acquired pottery items demonstrated that the pots were decorated with paint and glaze, which are common sources of contamination. Chemical analysis confirmed that these edible pots contained lead at concentrations up to 100,000 parts per million (or 1 percent), which is ten million times higher than the FDA guidelines for edible items.

Results of this preliminary research also highlight several clinical, social, and logistical barriers for research on edible pottery. In clinical settings, lead risk exposure questionnaires often make reference to use of pottery for cooking or storage, but do not inquire about the direct consumption of pottery. This results in a misdiagnosis of the threat or an incomplete description of all of the exposures that led to the poisoning, leading to an underreporting of lead-poisoning cases caused by the ingestion of contaminated pottery. The lack of a specific dose for the mother or fetus is a clinical barrier for comprehensive research on "pot eating". Perhaps most significantly, discussion of the behavior outside of the communities where this cultural practice is more common is limited by language barriers, social stigmas, and fear of cultural judgment.

Several physical barriers also limited the impact of research on "pot eating". In this research, the small sample size of pottery and the non-random acquisition of the samples analyzed in this report do not yield a reliably representative sample. Acquisition of a large sample of pots was challenging due to the stigmas and infrequency associated with this behavior. Additionally, in the existing research, only one of the four case studies reported the concentration of lead in the suspect piece of pottery, and the XRF units provided $\left(\mathrm{mg} / \mathrm{cm}^{2}\right)$ were not comparable to the units in the FDA action limit or the elemental analysis done in this study (ppm). Determination of the lead concentration in consumed pottery items is difficult as the entire pot is often ingested or discarded.

Future research should attempt to address these clinical, social, and physical barriers in a culturally sensitive manner. It is imperative that clinical research identify a maternal and fetal dose for "pot eating". Additionally, public health workers should endeavor to increase physiccian awareness of "pot eating" and to incorporate it into lead risk exposure questionnaires. Community-based participatory research should be utilized, in order to foster a collaborative approach to sensitively identify con- 
taminated pottery and increase knowledge on the dangers of lead exposure without stigmatization and judgment.

\section{ACKNOWLEDGEMENTS}

The manuscript was funded, in part, from a grant from the Centers for Disease Control and Prevention, (Grant \# 1H64EH000145-01).

The authors would like to thank numerous team members from the Southern Nevada Health District and Childhood Lead Poisoning Prevention Program, especially Keith Zupnik, Garren Jakubiak, Erika Torres, Brenda Argueta, and Jessica Newberry.

\section{REFERENCES}

[1] Smulian, J., Motiwala, S. and Sigman, R. (1995) Pica in rural obstetric population. Southern Medical Journal, 88, 1236-1240. doi:10.1097/00007611-199512000-00010

[2] Derman, O., Okstuz-Kanbur, N., Yenicesy, I. and Klink, E. (2005) Iron deficiency anemia in a group of Turkish adolescents: Frequency and contributing factors. International Journal of Adolescent Medicine and Health, 17, 179-186. doi:10.1515/IJAMH.2005.17.2.179

[3] Hamilton, S., Rothenberg, S., Khan, F., Manalo, M. and Norris, K. (2001) Neonatal lead poisoning from maternal pica behavior during pregnancy. Journal of the National Medical Association, 93, 317-319.

[4] MA, A.-K. and Bani, I. (1995) Food habits during pregnancy among Saudi women. International Journal for Vitamin and Nutrition Research, 65, 206-210.

[5] Bateson, E. and Lebroy, T. (1978) Clay eating by aboriginals of the northern territory. Medical Journal of Australia, 1, 1-3.

[6] Eastwell, H. (1979) A pica epidemic: A price for sedentarism among Australian ex-hunter-gatherers. Psychiatry, 42, 264-273.

[7] Edwards, C. (1959) Clay and cornstarch eating women. Journal of the American Dietetic Association, 35, 810815.

[8] Bruhn, C. and Panborn, R. (1971) Reported incidence of pica among migrant families. Journal of the American Dietetic Association, 58, 417-420.

[9] Avila, M., Romieu, I., Rios, C., Rivero, A. and Palazuelos, E. (1991) Lead-glazed ceramics as major determinants of blood lead levels in Mexican women. Environmental Health Perspectives, 94, 117-120. doi:10.2307/3431303

[10] Lynch, R., Boatright, D. and Moss, S. (2000) Lead-contaminated imported tamarind candy and children's blood lead levels. Public Health Reports, 115, 537-543. doi:10.1093/phr/115.6.537

[11] ATSDR (2005) Toxicological profile for lead. http://www.atsdr.cdc.gov/toxprofiles/phs13.html

[12] Rojas-Lopez, M., Santos-Burgoa, C., Rios, C., Hernandez-Avila, M. and Romieu, I. (1994) Use of lead-glazed ceramics is the main factor associated to high lead in blood levels in two Mexican rural communities. Journal of Toxicology and Environmental Health, 42, 45-52.
[13] Rothenberg, S., Manalo, M., Jian, J., Khan, F., Cuellar, R., Reyes, S., et al. (1999) Maternal blood lead level during pregnancy in South Central Los Angeles. Archives of Environmental Health, 54, 151-157.

[14] Donkin, S., Ohlson, D. and Teaf, C. (2000) Properties and effects of metals. In: Williams, P., James, R. and Roberts, S., Eds., Principles of Toxicology, John Wiley \& Sons, Inc., New York, 325-344. doi:10.1002/0471231800.ch14

[15] Middendorf, P. and Williams, P. (2000) Nephrotoxicity: Toxic responses of the kidney. John Wiley \& Sons, Inc., New York, 139-140.

[16] Bailey, C. and Kitchen, I. (1985) Ontogenesis of proenkephalin products in rat striatum and the Inhibitory effects of low-level lead exposure. Developmental Brain Research, 22, 75-79. doi:10.1016/0165-3806(85)90070-7

[17] Markovac, J. and Goldstein, G. (1988) Picomolar concentrations of lead stimulate brain protein kinase C. Nature, 334, 71-73. doi:10.1038/334071a0

[18] Holtzman, D., DeVries, C., Nguyen, H. and Bensch, K. (1984) Maturation of resistance to lead encephalopathy: Celular and subcellular mechanisms. Neurotoxicology, 5, 97-124.

[19] Needleman H. (2004) Lead poisoning. Annual Review of Medicine, 55, 209-222. doi:10.1146/annurev.med.55.091902.103653

[20] Needleman, H., Schell, A., Bellinger, D., Leviton, A. and Allred, E. (1990) The long-term effects of exposure to low doses of lead in childhood. An 11-year follow-up report. New England Journal of Medicine, 322, 83-88. doi:10.1056/NEJM199001113220203

[21] Rice, D. (1992) Behavioral impairment produced by developmental lead exposure: Evidence from primate reseach. In: Needleman, H., Ed., Human Lead Exposure, CRC, Boca Raton.

[22] Manton, W. (1985) Total contribution of airborne lead to blood lead. British Journal of Industrial Medicine, 42, 168-172.

[23] Rothenberg, S., Karchmer, S., Schnaas, L., Perroni, E., Zea, F., Salinas, V., et al. (1996) Maternal influences on cord blood lead levels. Journal of Exposure Analysis and Environmental Epidemiology, 6, 211-227.

[24] Viksna, A. and Lindgren, E. (1997) Determination of lead and cadmium in whole blood of mothers and their babies. Analytica Chimica Acta, 353, 307-311. doi:10.1016/S0003-2670(97)87790-2

[25] Robinson, C., Hall, J. and Beshir, S. (1983) Hormonal modulation of mineral metabolism in reproduction. Proceedings of the Nutrition Society, 42, 169-180. doi:10.1079/PNS19830022

[26] Miller, R. (1983) Perinatal toxicology: Its recognition and fundamentals. American Journal of Industrial Medicine, 4, 205-243. doi:10.1002/ajim.4700040118

[27] Garel, J. (1987) Hormonal control of calcium metabolism during the reproductive cycle in mammals. Physiological Reviews, 67, 1-66.

[28] Purdie, D., Aaron, J. and Selby, P. (1988) Bone histology and mineral homeostasis in human pregnancy. British 
Journal of Obstetrics and Gynaecology, 95, 849-854. doi:10.1111/j.1471-0528.1988.tb06568.x

[29] Rabinowitz, M. (1990) Toxicokinetics of bone lead. Environmental Health Perspectives, 91, 33-37. doi:10.1289/ehp.919133

[30] Averil, D. and Needleman, H. (1980) Neonatal lead exposure retards cortical synaptogenesis in the rat. In: Needleman, H., Ed., Low Level Lead Exposure: The Clinical Implications of Research, Raven Press, New York, 210220.

[31] Alexander, F. and Delves, H. (1981) Blood lead levels during pregnancy. International Archives of Occupational and Environmental Health, 48, 35-39. doi:10.1007/BF00405929

[32] Barltrop, D. (1969) Transfer of lead to the human fetus. In: Barland, D., Ed., Mineral Metabolism in Pediatrics, Davis, Philadelphia, 135-151.

[33] Gershanik, J., Brooks, G. and Little, J. (1974) Blood lead levels in pregnant women and their offspring. American Journal of Obstetrics \& Gynecology, 119, 508-511.

[34] Borella, P., Picco, P. and Masellis, G. (1986) Lead content in abortion material from urban women in early pregnancy. International Archives of Occupational and Environmental Health, 57, 93-99. doi:10.1007/BF00381376

[35] Graziano, J., Popovac, D., Factor-Litvak, P., Shrout, P., Kline, J., Murphy, M., et al. (1990) Determinants of elevated blood lead during pregnancy in a population surreounding a lead smelter in Kosoud, Yugoslavia. Environmental Health Perspectives, 89, 95-100. doi:10.1289/ehp.908995

[36] Robinson, M., Karpinski, F. and Brieger, H. (1958) The concentration of lead in plasma, whole blood, and erythrocytes of infants and children. Pediatrics, 21, 693.

[37] Newland, M., Yezhou, S., Logdberg, B. and Berlin, M. (2002) Prolonged behavioral effects of in utero exposure to lead or methyl mercury: Reduced sensitivity to changes in reinforcement contingencies during behavioral transitions and in steady state. Toxicology and Applied Pharmacology, 126, 6-15. doi:10.1006/taap.1994.1084

[38] Bellinger, D., Leviton, A. and Sloman, J. (1990) Antecedants and correlates of improved cognitive performance in children exposed in utero to low levels of lead. Environmental Health Perspectives, 89, 5-11. doi:10.1289/ehp.90895

[39] Bellinger, D., Needleman, H., Leviton, A., Waternaux, C., Rabinowitz, M. and Nichols, M. (1984) Early sensorymotor development and prenatal exposure to lead. Neurobehavioral Toxicology \& Teratology, 6, 387-402.

[40] Baghurst, P. (1992) Environmental exposure to lead and children's intelligence at the age of seven years: The port pirie cohort study. New England Journal of Medicine, 327, 1279. doi:10.1056/NEJM199210293271805

[41] Lowry, L., Cherry, D., Brady, C., Huggins, B., D’Sa, A. and Levin, J. (2004) An unexplained case of elevated blood lead in a Hispanic child. Environmental Health Perspectives, 112, 222-225. doi:10.1289/ehp.6486

[42] Mycyk, M. and Leilan, J. (2004) Combined exchange transfusion and chelation therapy for neonatal lead poisoning. The Annals of Pharmacotherapy, 38, 821-824. doi:10.1345/aph.1D475

[43] Erdem, G., Hernandez, X., Kyono, M., Chan-Nishina, C. and Iwaishi, L. (2004) In-utero lead exposure after maternal ingestion of Mexican pottery: Inadequacy of the lead exposure questionnaire. Clinical Pediatrics, 43, 185. doi:10.1177/000992280404300209

[44] Administration UFaD (2000) EAM 4.1 flame atomic absorption spectrometric determination of lead and cadmium extracted from ceramic foodware. FDA Elemental Analysis Manual for Food and Related Products.

[45] Administration UFaD (2004) CPG Sec 545.450 pottery (ceramics); import and domestic-Lead contamination.

[46] Administration UFaD (2000) Action levels for poisonous or deleterious substances in human food and animal feed. 